九州大学学術情報リポジトリ

Kyushu University Institutional Repository

Effect of culture conditions on Growth and Lipase Production by A Newly Isolated Strain, Geotrichum-like R59 (Basidiomycetes)

Ginalska, Gryzyna

Marie Curie-Sk Lodowska University

Cho, Hee-Yeon

Dental Research Institute, School of Dentistry, UCLA

Cho, Nam-Seok

School of Eorest and Rural Engineering, Chungbuk National University

Bancerz, Renata

Marie Curie-Sk Lodowska University

他

https://doi.org/10.5109/9276

出版情報: 九州大学大学院農学研究院紀要. 52 (1)，pp. 29-34，2007-02-28. Faculty of Agriculture， Kyushu University

バージョン:

権利関係： 


\title{
Effect of Culture Conditions on Growth and Lipase Production by A Newly Isolated Strain, Geotrichum-like R59 (Basidiomycetes)
}

\author{
Gryzyna GINALSKA ${ }^{1}$, Hee-Yeon $\mathrm{CHO}^{2}$, Nam-Seok $\mathrm{CHO}^{3}$, Renata BANCERZ ${ }^{1}$, \\ Teresa KORNItOWICZ ${ }^{1}$, Andrzej LEONOWICZ ${ }^{1}$, Soo-Jeong SHIN ${ }^{3}$ \\ and Shoji OHGA*
}

\author{
Laboratory of Forest Resources Management, Division of Forest Ecosphere Management, \\ Department of Forest and Forest Products Sciences, Kyushu University, \\ Sasaguri, Fukuoka 811-2415, Japan \\ (Received November 9, 2006 and accepted December 1, 2006)
}

\begin{abstract}
Growth and production of lipase by a new isolant Geotrichum-like R59 were studied. Production of extracellular lipase was substantially enhanced when the initial $\mathrm{pH}$ of the culture medium, types of carbon and nitrogen sources, those of inducers of lipase biosynthesis, temperature and time of growth were optimized. Sucrose and triolein were the most effective compounds for lipase production. Maximum lipase production was obtained when urea was used as nitrogen source $(146 \mathrm{U} / \mathrm{ml})$. Temperature of $30^{\circ} \mathrm{C}$, the initial $\mathrm{pH}$ of 6.0 and incubation time of $48 \mathrm{~h}$ were found as optimum conditions for cell growth and production of lipase by Geotrichum-like R59 strain. The enzyme presented a good thermostability and still exhibited very high activity after $1 \mathrm{~h}$ incubation at $60^{\circ} \mathrm{C}$.
\end{abstract}

\section{INTRODUCTION}

Lipases are defined as glycerol ester hydrolases (EC3.1.1.3) hydrolyzing tri-, di- and mono-glycerides present at oil-water interface(Saxena et al., 1999). Some lipases are also able to catalyze esterification, trans-esterification and enantioselective hydrolysis reactions (Nini et al., 2001; Shintre et al., 2002; Nagayama et al., 2002; Piao et al., 2003; Kui et al., 2003; Raku et al., 2003). The interest in microbial lipase production has increased in the last decades, because of its large potential in a wide range of industrial applications as additives in food processing (flavor modification), fine chemicals (synthesis of esters), detergents (hydrolysis of fats), waste water treatment (decomposition and removal of oil substances), diagnostics, cosmetics (removal of lipids), pharmaceuticals (digestion of oil and fats in foods), leather (removal of lipids from animal skins) and medical (blood triglyceride assay) (Sarkar et al., 1998; Cardenas et al., 2001; Elibol and Ozer, 2000; Kamini et al., 2000).

Lipases are produced by many microorganisms (Kamimura et al., 2001; Elibol and Ozer, 2000) and higher eukaryotes. Enzyme-producing microorganisms include bacteria (Kulkarni and Gadre, 2002), fungi (Fodiloglu and Erkmen, 1999; Shimada et al., 1992), yeast (Corzo and Revah, 1999) and actinomycetes (Sommer et al., 1997). Especially lipases from microor-

\footnotetext{
${ }^{1}$ Department of Biochemistry, Marie Curie-Sklodowska University, Lublin 20-031, Poland

2 Dental Research Institute, School of Dentistry, UCLA, LA, California 90095, USA

${ }^{3}$ School of Forest Resources and Rural Engineering, Chungbuk National University, Cheongju 361-763, Korea

${ }^{4}$ Dept. of Forest and Forest Products Science, Kyushu University, Sasaguri, Fukuoka 811-2415, Japan

* Corresponding author (E-mail: ohgasfor@mbox.nc.kyushu-u. ac.jp)
}

ganisms have drawn much attention for their potential use in biotechnology, mainly due to their availability and stability (Ghosh et al., 1996; Wang et al., 1995). The lipase from Geotrichum candidum is currently the subject of intense investigation and industrial interest because it shows a strong preference for fatty acids that contain a cis-9 double bound (Bertolini et al., 1994; Jacobsen and Poulsen, 1995; Macedo et al., 1997). Recently optimization of extracellular lipase production by Geotrichum sp. using factorial design was conducted (Burkert et al., 2004). The response surface methodology was applied for the optimization of the nutrient concentrations in the culture medium for the enzyme production, at $30^{\circ} \mathrm{C}$. The optimum medium composition for lipase production by Geotrichum sp. was ammonium nitrate $2.1-2.5 \%$, corn steep liquor $13-15 \%$ and soy oil $0.6 \%$ as carbon source, which lead to a lipase activity of about $20 \mathrm{U} / \mathrm{ml}$. Using olive oil as carbon source, the optimum composition was ammonium nitrate $0.8-1 \%$, corn steep liquor $13-15 \%$ and olive oil $0.6 \%$, leading to an activity of $17 \mathrm{U} / \mathrm{ml}$.

The aim of this study was to determine the culture conditions for maximum lipase production by a newly isolated Geotrichum-like R59 (Basidiomycete) and to characterize the lipase enzyme. Medium composition, initial $\mathrm{pH}$, temperature and time of incubation were examined for optimization of the production of lipase. Lipase was characterized with respect to the optimal temperature and $\mathrm{pH}$, as well as to its stability.

\section{MATERIALS AND METHODS}

\section{Isolation of fungus}

The new strain of Geotrichum-like R59 (Basidiomycetes) was isolated from black soil ( $\mathrm{pH} 7.6$, $50-60 \%$ of humidity), by a method of trapping soil microorganisms on daunomycine-rich pulp, buried in caprone bags for the period of 3 months. The trapped 
organisms were sieved on agarized medium consisting of $1.5 \mathrm{~g} / \mathrm{l}$ of $\mathrm{KH}_{2} \mathrm{PO}_{4}, 300 \mathrm{ppm}$ of streptomycin and $10 \%$ of daunomycin-rich solid material in a dispersed form as main source of carbon and nitrogen. After three-week growth, only one place on a number of Petri dishes was decolorized and the fungal mycelium was isolated from this place. After isolation, the fungus was cultivated on agarized GZ medium (spud $300 \mathrm{~g} / \mathrm{l}$; glucose $20 \mathrm{~g} / \mathrm{l}$; agar $20 \mathrm{~g} / \mathrm{l})$.

\section{Growth media and culture conditions}

Basal GKM medium for lipase production contained: $10 \mathrm{~g} / \mathrm{l}$ glucose; $6 \mathrm{~g} / \mathrm{KH}_{2} \mathrm{PO}_{4} ; 1 \mathrm{~g} / \mathrm{l} \mathrm{MgSO}_{4} \times 7 \mathrm{H}_{2} \mathrm{O} ; 4 \mathrm{~g} / \mathrm{l}$ urea; $10 \mathrm{mg} / \mathrm{l} \mathrm{FeCl}_{3} \times 4 \mathrm{H}_{2} \mathrm{O} ; 8 \mu \mathrm{g} / \mathrm{l}$ d-biotin; $4 \mu \mathrm{g} / \mathrm{l}$ myo-inositol; $200 \mu \mathrm{g} / \mathrm{l}$ thiamin and $10 \mathrm{~g} / \mathrm{l}$ olive oil (Ota $e t$ al., 1968). The $\mathrm{pH}$ of the medium was adjusted to 6.0 by addition of $\mathrm{KOH}$. The culture medium without urea and vitamins was sterilized at $121^{\circ} \mathrm{C}$ for $25 \mathrm{~min}$. After cooling, the urea and the vitamins were added to the medium.

To observe the effect of the initial pH of GKM medium on lipase production, $\mathrm{pH}$ of the medium varied from 3.0-11.0. While studying the effects of inducers, olive oil was replaced by similar concentrations of other inducers (fatty acids, triacylglycerols and oils). Next glucose was replaced by other sugars (maltose, galactose, xylose, fructose, lactose, sucrose and starch at concentrations of 1\%) for the effect of carbon source. Then to test the effect of different nitrogen source on lipase production, urea was replaced by other nitrogen containing compounds (peptone, yeast extract, casein, asparagine, ammonium nitrate, sodium nitrate and diammonium hydrogen orthophosphate at concentrations of $1 \%$ ).

The flasks containing $25 \mathrm{ml}$ of medium were inoculated with $1 \mathrm{ml}$ suspension of Geotrichum-like mycelium, grown earlier in the basal medium and cultured for 2 days at $30^{\circ} \mathrm{C}$ on rotary shaker operating at $150 \mathrm{rpm}$.

\section{Lipase and protein assays}

Lipase activity was determined by the method of Sokolovska et al. with some modifications. $0.5 \mathrm{ml}$ of lipase solution were mixed with $1 \mathrm{ml} 50 \mathrm{mM}$ phosphate buffer $\mathrm{pH} 7.0$ and $1.5 \mathrm{ml}$ of tributyrin in $25 \mathrm{ml}$ Erlenmeyer flasks. After $60 \mathrm{~min}$. incubation at $37^{\circ} \mathrm{C}$ the emulsion was mixed with a $1 \mathrm{ml}$ acetone: ethanol mixture $(1: 1)$ to extract free fatty acids. Finally, their concentration was determined by titration $(0.05 \mathrm{~N} \mathrm{KOH})$ using phenolphthalein as indicator. One unit (U) of lipase activity is defined as amount of the enzyme releasing $1 \mu \mathrm{mol}$ of free fatty acids per minute under assay conditions.

Protein concentration was estimated by the method of Lowry with bovine serum albumin as a standard (Lowry et al., 1951).

\section{Effect of the initial $\mathrm{pH}$, temperature and time of incubation}

The effect of temperature and time of incubation on growth and lipase production was studied in the opti- mized medium. For selection of the optimum temperature for the production of lipase, the temperature of the culture varied from $10-40{ }^{\circ} \mathrm{C}$. The effect of incubation time on lipase production was studied in shake flasks incubated for 6 days.

\section{Characterization of lipase}

Geotrichum-like fungus was grown in the optimized medium for $48 \mathrm{~h}$ at $30^{\circ} \mathrm{C}$ and the mycelium was removed by centrifugation at $12,000 \mathrm{rpm}$ for $15 \mathrm{~min}$ at $4^{\circ} \mathrm{C}$. The temperature optimum for the activity of the crude enzyme was evaluated using lipase activity assay with tributyrin at different temperatures. The activity assay was performed at pH 7.0. Enzyme stability at various temperatures was studied by incubating lipase within the range of $30-90^{\circ} \mathrm{C}$ for 30 and $60 \mathrm{~min}$ each, followed by activity estimation at $37^{\circ} \mathrm{C}$.

Lipase activity was estimated following $\mathrm{pH}$ values within the range $\mathrm{pH}$ 3.0-10.0 to determine the optimal $\mathrm{pH}$. The substrate specificity towards different triacylglycerols and oils was analyzed by titration method as described above.

\section{RESULTS AND DISCUSSION}

\section{Identification and characterization of Geotrichum-like fungus}

The investigated strain R59 is ranked among quick growing fungi: after a 5-day growth on GZ medium, it forms colonies reaching a $9-\mathrm{cm}$ diameter. These hyaline fungi are characteristic of a good development of the surface mycelium, and of a fibrous structure. Microscopic micromorphological studies of the colony showed strain R59 to produce forky ramifications of vegetative hyphae and arthroconidia formed by hypha fragmentation. Having considered that the aforesaid characteristics bring this strain closer to genus Geotrichum (Domsch et al., 1980), belonging to imperfect fungi (subgroup Deuteromycotina, class Hyphomycetes), it was initially defined as Geotrichum-like. There was found an essential morphological difference between typical representative of Geotrichum, i.e. Geotrichum candidum, and strain R59 in distinct character and structure of their colony. The strain we isolated from the soil forms typical mold colonies consisting of a high, relatively loose and well-developed mycelium, in contrast with Geotrichum candidum forming flat yeast-like colonies with a highly reduced vegetative surface mycelium, hoarfrost covered mass conidia.

\section{Effect of initial pH of the culture medium}

Fig. 1 shows the effect of the $\mathrm{pH}$ of medium on lipase production. The maximum lipase activity was obtained when the initial $\mathrm{pH}$ of the GKM medium was 6.0, although $\mathrm{pH}$ 3.0-9.5 favored lipase production. However, lipase production dropped significantly at $\mathrm{pH}$ 9.5. No production of lipase was observed at $\mathrm{pH}$ 9.5-11.0. The lipase from G. candidum (Baillargeon et al., 1989) showed the highest activity when the initial $\mathrm{pH}$ of the medium was adjusted to $\mathrm{pH}$ 7.0. On the con- 


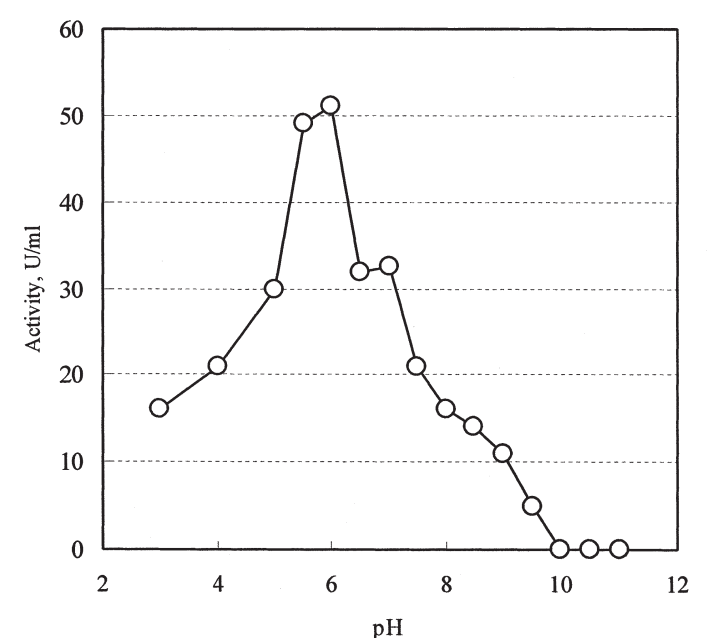

Fig. 1. Effect of $\mathrm{pH}$ medium on lipase production by Geotrichum-like grown on GKM medium.

trary, lipase production from the newly isolated strain of Geotrichum sp. was maximum at pH 5.0 (Macedo et al., 1997).

\section{Effect of inducers}

Among various oils, triglycerides and fatty acids tested at concentrations of a $1 \%$, triolein allowed for maximum lipase production $-91 \mathrm{U} / \mathrm{ml}$ (Table 1.). A similar result was reported for synthesis of lipase from Cryptococcus sp. S-2 (Kamini et al., 2000). Rape oil, soybean oil and olive oil were also proved to be effective inducers for lipase production by Geotrichum-like R59 (lipase activity were $82.4 \mathrm{U} / \mathrm{ml}, 71 \mathrm{U} / \mathrm{ml}$ and $69 \mathrm{U} / \mathrm{ml}$, respectively). For lipase production, soybean oil was also used from strain Geotrichum candidum ATCC 34614 (Baillargeon et al., 1989). In the presence of triglycerides with saturated short-chain fatty acids (tributyrin and tricaprylin) Geotrichum-like species showed little production of lipase $(6.5 \mathrm{U} / \mathrm{ml}$ and $3.0 \mathrm{U} / \mathrm{ml}$, respectively). Saturated short-chain caprylic acid did not induce lipase production. These results were in accordance with studies on Geotrichum candidum ATCC 34614 (Shimada et al., 1992).

Table 1. Effect of inducers on lipase production

\begin{tabular}{lcc}
\hline \multicolumn{1}{c}{ Inducers } & $\begin{array}{r}\text { Activity } \\
{[\mathrm{U} / \mathrm{ml}]}\end{array}$ & $\begin{array}{c}\text { Protein } \\
{[\mathrm{mg} / \mathrm{ml}]}\end{array}$ \\
\hline Control ${ }^{*}$ & 10.0 & 0.30 \\
Tributyrin & 6.5 & 0.28 \\
Tricaprylin & 3.0 & 0.40 \\
Triolein & 91.0 & 0.31 \\
Soybean oil & 71.0 & 1.20 \\
Rape oil & 82.4 & 1.30 \\
Corn oil & 40.0 & 0.76 \\
Olive oil & 69.0 & 0.24 \\
Oleic acid & 13.5 & 0.40 \\
Caprylic acid & 0 & 0.26 \\
\hline
\end{tabular}

*control-without inducers

\section{Influence of carbon source on lipase production}

In GKM medium, glucose was replaced by other carbon sources. These carbohydrates were optimized at concentrations of 1\%. Geotrichum-like strain grew and produced lipase on all tested medium. The best result was observed for sucrose present in the medium (Table 2).

Table 2. Effect of carbon source on lipase activity

\begin{tabular}{lrl}
\hline $\begin{array}{c}\text { Carbon source } \\
{[1 \%]}\end{array}$ & $\begin{array}{r}\text { Activity } \\
{[\mathrm{U} / \mathrm{ml}]}\end{array}$ & $\begin{array}{c}\text { Protein } \\
{[\mathrm{mg} / \mathrm{ml}]}\end{array}$ \\
\hline Control $*$ & 28.0 & 0.23 \\
Lactose & 29.5 & 0.19 \\
Maltose & 24.5 & 0.19 \\
Starch & 30.0 & 0.12 \\
Sucrose & 118.0 & 0.47 \\
Xylose & 26.0 & 0.57 \\
Glucose & 92.4 & 0.40 \\
Fructose & 1.0 & 0.16 \\
Galactose & 82.0 & 0.34 \\
\hline
\end{tabular}

*control-without carbohydratess

The activity of lipase synthesized under these conditions was of $118 \mathrm{U} / \mathrm{ml}$. Glucose and starch were also good carbon source for growth and production of lipase. However, Baillargeon et al. (1989) showed that lipase production was not detected in the medium containing glucose or sucrose. The lowest lipase activity was obtained, when adding fructose to the basal medium (only $1 \mathrm{U} / \mathrm{ml}$ ). In contrast, fructose was reported to be the best carbohydrate for production of extracellular lipase by Rhodotorula glutinis (Papaparaskevas et al., 1992). Fig. 2 showed data for lipase production for the range of sucrose concentration tested in the experiment. The highest level of lipase activity was obtained after using sucrose at a concentration of $0.5 \%(146 \mathrm{U} / \mathrm{ml})$. When higher concentrations of sucrose were added to GKM medium, lipolytic activity decreased.

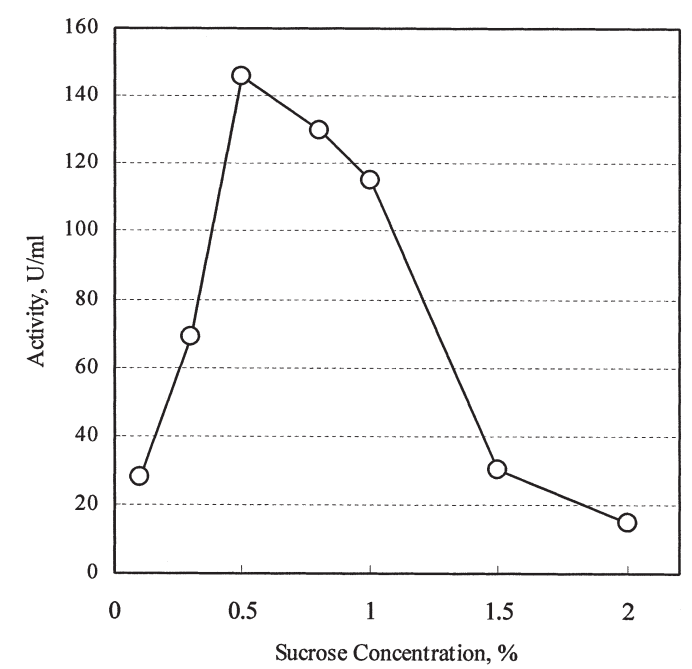

Fig. 2. Lipase production by Geotrichum-like R59 at various concentration of sucrose. 


\section{Effect of nitrogen source on lipase production}

The effect of nitrogen source was tested in the GKM medium by removing urea and replacing it with selected nitrogen sources (both organic and inorganic). As shown in Fig. 3, the best result was observed for urea at a concentration of $0.4 \%$ (lipase production improved to $146 \mathrm{U} / \mathrm{ml}$ ). Generally, microorganisms provide high yields of lipase when organic nitrogen is used. Yarrowia lipolytica produced extracellular lipase in a medium containing urea at a concentration of $0.2 \%$ (Corzo and Revah, 1999). Salleh et al. (1993) obtained maximal production of extracellular lipase by fungi Rhizopus oryzae, when the medium contained peptone as nitrogen source. Among other organic nitrogen sources tested (peptone, yeast extract, casein and asparagine), none increased lipase production significantly (in each case lipase activity was below $30 \mathrm{U} / \mathrm{ml}$ ).

The inorganic nitrogen sources (see Fig. 3) showed an inhibitory effect on lipase production. Similar results have been reported by Sarkar et al. (1998).

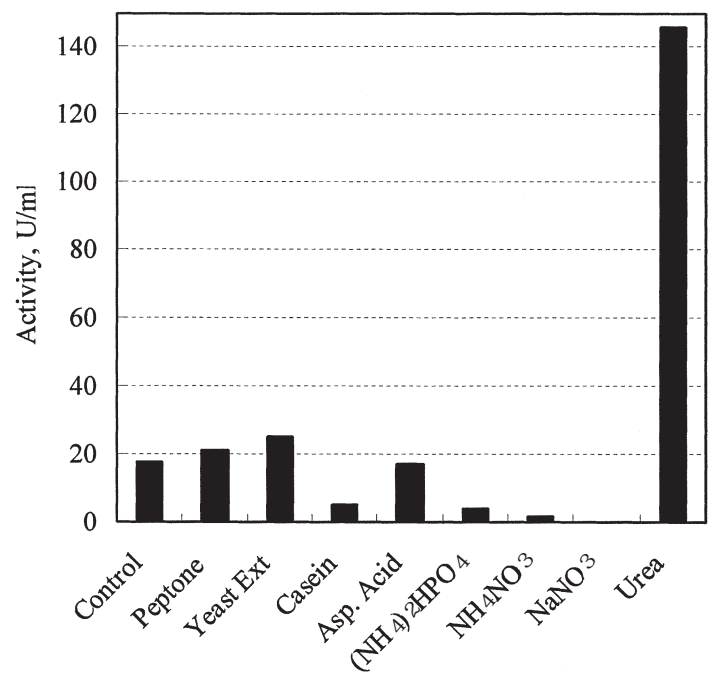

Fig. 3. Effect of nitrogen source on lipase activity.

\section{Effect of the temperature and time of incubation on lipase production}

Table 3 shows the effect of temperature and incubation time on lipase production. Geotrichum-like strain was grown at temperatures from 5 to $40^{\circ} \mathrm{C}$ on optimized
GKM medium. The best conditions for lipase production and cell growth were $30^{\circ} \mathrm{C}$ and $48 \mathrm{~h}$ of incubation (the total lipase activity and the biomass were maximum-150 U/ml and $1.04 \mathrm{~g} / \mathrm{l}$, respectively). The results of biomass were affected principally by the temperature and time of incubation. Similar results were reported for Geotrichum sp., which was incubated at $30^{\circ} \mathrm{C}$ for 48 hours (Macedo et al., 1997). Baillargeon et al. (1989) also reported that maximal lipase activity from Geotrichum candidum ATCC 34614 was found at $30^{\circ} \mathrm{C}$, but after 24 hours. Geotrichum-like species also presented high lipolytic activities when incubated at $25^{\circ} \mathrm{C}$ for 4 days, but in that case the biomass was low $(0.65 \mathrm{~g} / \mathrm{l})$. Geotrichum-like fungus was also grown at a temperature of $5^{\circ} \mathrm{C}$, but maximum lipase production was observed after 10-day incubation (30 U/ml) - data not shown.

\section{Enzyme characterization}

A comparison of the results of hydrolysis of several triglycerides and oils showed tributyrin to be the best substrate for Geotrichum-like extracellular lipase (Fig. 4). Lipase activity against tributyrin was taken for $100 \%$. Lipase was more active on synthetic triacylglycerides (tributyrin, tricaprylin and triolein) than on natural oils. A high relative activity of lipase was observed for tricaprylin (70\%). Lipase from Yarrowia lipolytica 681 (Corzo and Revah, 1999) and Bacillus thermoleovorans ID-1 (Lee et al., 1999) also showed the greatest activity for tricaprylin as substrate.

Temperature and $\mathrm{pH}$ optimum were detected in the presence of tributyrin as substrate. The optimum $\mathrm{pH}$ for lipase activity was examined in the range of $\mathrm{pH}$ 3.0-11.0. The lipase activity estimation at different $\mathrm{pHs}$ showed the optimum pH of lipase from Geotrichum-like R59 to be pH 7.0. As seen on Fig. 5, lipase activity decreased significantly above $\mathrm{pH}$ 8.0. The results were in accordance with studies on Yarrowia lipolytica 681 (Corzo and Revah, 1999). Conversely, crude lipase from Geotrichum sp. (Macedo et al., 1997) was most active between $\mathrm{pH}$ 7.5-9.0.

Fig. 6 showed that the crude lipase from Geotrichum-like R59 exhibited two optimal activities: at $37^{\circ} \mathrm{C}$ and $50{ }^{\circ} \mathrm{C}$. The results suggested that this strain produced multiple forms of lipase with different optimum temperatures. This is similar to the report on

Table 3. Effect of the temperature and incubation time on lipase activity

\begin{tabular}{ccccccccccc}
\hline & \multicolumn{10}{c}{ Growth temperature } \\
\cline { 2 - 10 } $\begin{array}{c}\text { Day of } \\
\text { incubation }\end{array}$ & \multicolumn{2}{c}{$18^{\circ} \mathrm{C}$} & \multicolumn{2}{c}{$25^{\circ} \mathrm{C}$} & \multicolumn{3}{c}{$30^{\circ} \mathrm{C}$} & $35^{\circ} \mathrm{C}$ & $40^{\circ}$ \\
\cline { 2 - 11 } & $\begin{array}{c}\text { Activity } \\
{[\mathrm{U} / \mathrm{ml}]}\end{array}$ & $\begin{array}{c}\text { Biomass } \\
{[\mathrm{g} / \mathrm{l}]}\end{array}$ & $\begin{array}{c}\text { Activity } \\
{[\mathrm{U} / \mathrm{ml}]}\end{array}$ & $\begin{array}{c}\text { Biomass } \\
{[\mathrm{g} / \mathrm{l}]}\end{array}$ & $\begin{array}{c}\text { Activity } \\
{[\mathrm{U} / \mathrm{ml}]}\end{array}$ & $\begin{array}{c}\text { Biomass } \\
{[\mathrm{g} / \mathrm{l}]}\end{array}$ & $\begin{array}{c}\text { Activity } \\
{[\mathrm{U} / \mathrm{ml}]}\end{array}$ & $\begin{array}{c}\text { Biomass } \\
{[\mathrm{g} / \mathrm{l}]}\end{array}$ & $\begin{array}{c}\text { Activity } \\
{[\mathrm{U} / \mathrm{ml}]}\end{array}$ & $\begin{array}{c}\text { Biomass } \\
{[\mathrm{g} / \mathrm{l}]}\end{array}$ \\
\hline $1^{\text {st }}$ & 5.0 & 0.63 & 10.0 & 0.80 & 32.0 & 0.89 & 59.0 & 0.89 & 25.0 & 0.83 \\
$2^{\text {nd }}$ & 8.0 & 0.71 & 17.0 & 0.82 & 150.0 & 1.04 & 75.0 & 0.95 & 53.0 & 0.97 \\
$3^{\text {rdd }}$ & 24.5 & 0.74 & 34.0 & 0.82 & 82.0 & 0.91 & 49.0 & 0.92 & 31.0 & 0.95 \\
$4^{\text {th }}$ & 41.0 & 0.77 & 85.0 & 0.65 & 61.0 & 0.79 & 29.0 & 0.69 & 25.0 & 0.89 \\
$5^{\text {th }}$ & 30.0 & 0.79 & 76.0 & 0.63 & 28.0 & 0.79 & 19.0 & 0.89 & 13.0 & 0.72 \\
$6^{\text {th }}$ & 24.0 & 0.97 & 43.0 & 0.55 & 10.0 & 0.75 & 8.0 & 0.70 & 6.0 & 0.71 \\
\hline
\end{tabular}




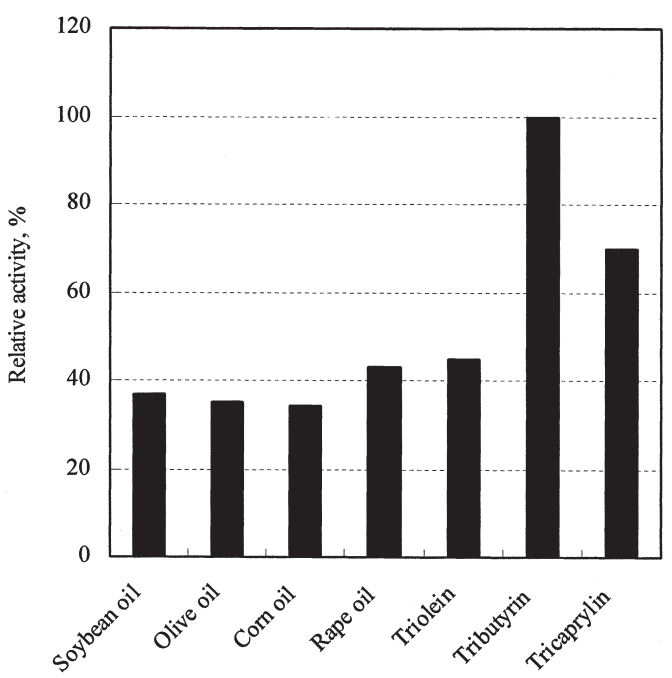

Fig. 4. Substrate specificity of lipase from Geotrichum-like R59.

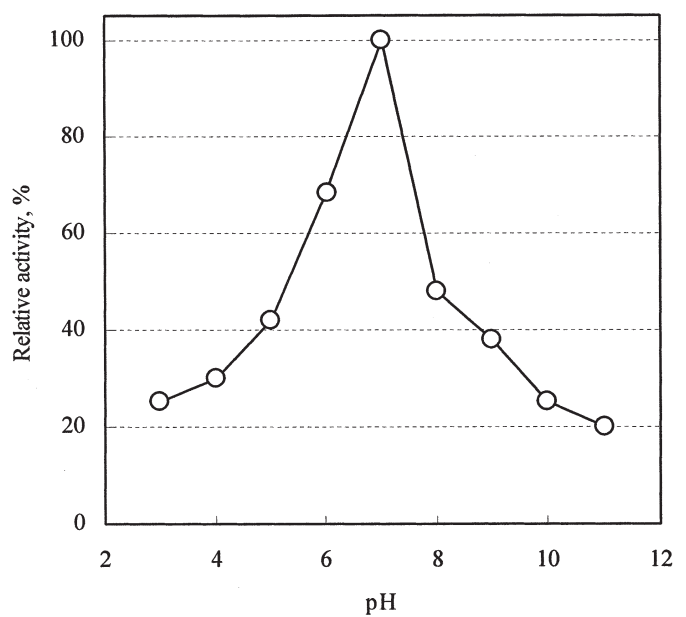

Fig. 5. Effect of $\mathrm{pH}$ on lipase activity.

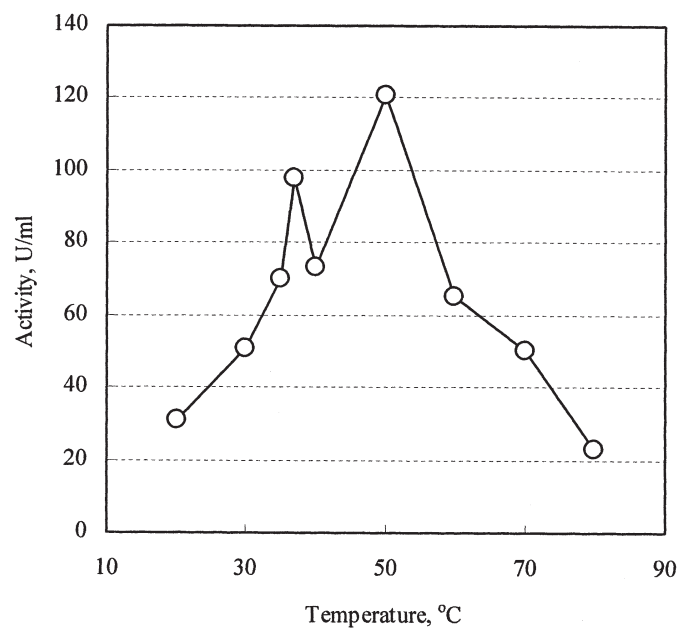

Fig. 6. Effect of temperature on lipase activity.

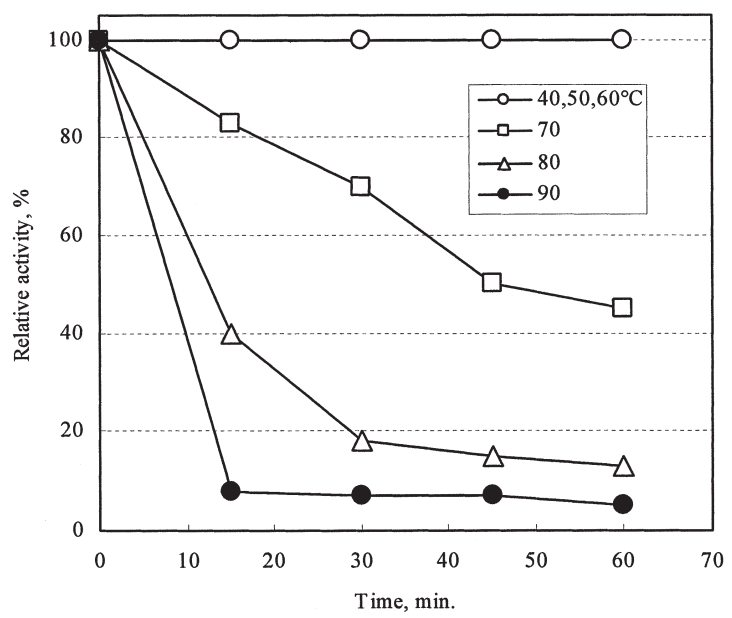

Fig. 7. Thermostability of lipase.

lipase production by Geotrichum candidum strain, where the optimum temperatures of lipase I and II were $30^{\circ} \mathrm{C}$ and $40^{\circ} \mathrm{C}$, respectively (Sugihara et al., 1990).

Fig. 7 shows that lipase from Geotrichum-like species presented a good thermostability. The enzyme appeared to be stable and fully active after incubation at $60 \mathrm{oC}$. It retained $50 \%$ of its initial activity when heated at $70^{\circ} \mathrm{C}$ for $45 \mathrm{~min}$.

It is noteworthy that Geotrichum-like strain R59 isolated from soil is a very good producer of extracellular enzyme exhibiting a very high lipolytic activity. Especially owing to its short period of growth (48h) and high thermostability, it seems to be of a high biotechnological significance. With respect to the enzymatic processing of lipids, thermostable lipase from different strains seems very useful in industry and lipase-producing microorganisms can also be used to develop the process of lipid hydrolysis.

\section{CONCLUSIONS}

This study was carried out to determine the culture conditions for maximum lipase production by a newly isolated Geotrichum-like R59 (Basidiomycete) and to characterize the enzyme. Medium composition, initial $\mathrm{pH}$, temperature and time of incubation were also examined for optimization of the production of lipase. Lipase was characterized with respect to the optimal temperature and $\mathrm{pH}$, as well as to its stability.

Geotrichum-like strain R59 isolated from soil was confirmed is a very good lipase producer of extracellular enzyme. Sucrose and triolein were the most effective compounds for lipase production. The maximum lipase activity was obtained when the initial $\mathrm{pH}$ of the GKM medium was 6.0, although $\mathrm{pH}$ 3.0-9.5 favored lipase production. Among various oils, triglycerides and fatty acids tested at concentrations of a $1 \%$, triolein allowed for maximum lipase production. Maximum lipase production was obtained when urea was used as nitrogen source $(146 \mathrm{U} / \mathrm{ml})$. Temperature of $30^{\circ} \mathrm{C}$, the initial $\mathrm{pH}$ 
of 6.0 and incubation time of $48 \mathrm{~h}$ were found as optimal conditions for cell growth and production of lipase by Geotrichum-like R59 strain.

The crude lipase from Geotrichum-like R59 exhibited two optimal activities: at $37^{\circ} \mathrm{C}$ and $50{ }^{\circ} \mathrm{C}$. The results suggested that this strain produced multiple forms of lipase with different optimum temperatures. The enzyme appeared to be a very good thermostability and fully active even after $1 \mathrm{~h}$ incubation at $60^{\circ} \mathrm{C}$.

\section{ACKNOWLEDGEMENT}

This work was supported by the Polish Science Committee BS/BiNoZ/4 and European Community (Contract ICA2-CT-2000-10050) and the Polish Committee for Scientific Investigations 139/E-339/SPUB-M-5PR-UE/DZ 280/200.

\section{REFERENCES}

Baillargeon M. W., R. G. Bistline Jr. and P. E. Sonnet 1989 Evaluation of srains of Geotrichum candidum for lipase production and fatty acid specificity. Appl. Microbiol. Biotechnol., 30: 92-96

Bertolini, M. C., L. Laramee, D. Y. Thomas, M. Cygler, J. D. Schrag, T. Vernet 1994 Polymorphism in the lipase genes of Geotrichum candidum strains. Europ. J. Biochem., 219: 119-125

Burkert, J. F. M., F. Maugeri and M. I. Rodrigues 2004 Optimization of extracellular lipase production by Geotrichum sp. using factorial design. Bioresource Technol. 91: $77-84$

Cardenas J., E. Alvarez, M.-S. de Castro-Alvarez, J.-M. Sanchez-Montero, M. Valmaseda, S. W. Elson, and J.-V. Sinisterra 2001 Screening and catalytic activity in organic synthesis of novel fungal and yeast lipases. J. Mol. Catal. B: Enzym., 14: 111-123

Corzo R. and S. Revah 1999 Production and characteristics of the lipase from Yarrowia lipolytica 681. Bioresource Technol., 70: 173-180

Domsch K. H., W. Gams and T. H. Anderson 1980 Compendium of Soil Fungi, Vol. 1. Academic Press, London

Elibol, M. and D. Ozer 2000 Influence of oxygen transfer on lipase production by Rizopus arrhizus. Proc. Biochem., 36: 325-329

Fodiloglu S. and O. Erkmen 1999 Lipase production by Rhizopus oryzae growing on different carbon and nitrogen sources. J. Sci. Food Agri., 79: 1936-1938

Ghosh P. K., T. K. Saxena, R. Gupta, R. P. Yadav and S. Davidson 1996 Microbial lipases: Production and Applications. Sci. Prog., 79: 119-157

Jacobsen, T. and O. M. Poulsen 1995 Comparison of lipases from different strains of the fungus Geotrichum candidum. Biochim. Biphys. Acta Lipids Metabolism, 1257: 96-102

Kamimura, E. S., O. Medieta, M. I. Rodrigues and F. Maugeri 2001 Studies on lipase-affinity adsorption using response-surface analysis. Biotechnol. Appl. Biochem., 33: 153-159

Kamini, N. R., T. Fujii, T. Kurosu and H. Iefuji 2000 Production, purification and characterization of an extracellular lipase from yeast, Cryptococcus sp. S-2. Proc. Biochem., 36: 317-324

Kui, T., X. Xu, C. He and L. Li 2003 Lipase-catalysed modifica- tion of lard to produce human milk fat substitutes. Food Cap Chem., 80: 473-481

Kulkarni N. and R. V. Gadre 2002 Production and properties of an alkaline, thermophilic lipase from Pseudomonas fluorescens NS2W. J. Industrial Microbiol. Biotechnol., 28: $344-348$

Lee D.-W., Y.-S. Koh, K.-J. Kim, B.-C. Kim, H.-J. Choi, D.-D. Kim, M. T. Suhartono and Y.-R. Pyun 1999 Isolation and characterization of a thermophilic lipase from Bacillus thermoleovorans ID-1. FEMS Microbiol. Lett., 179: 393-400

Lowry O. H., N. J. Rosebrough, A. L. Farr and R. J. Randall 1951 Protein measurement with the Folin phenol reagent. J. Biol. Chem., 193: 265-275

Macedo G. A., Y. K. Park and G. M. Pastore 1997 Partial purification and characterization of an extracellular lipase from a newly isolated strain of Geotrichum sp. J. Brazil. Soc. Microbiol., 28: 90-95

Nagayama, K., N. Yamasaki and M. Imai 2002 Fatty acid esterification catalyzed by Candida rugosa lipase in lecithin microemulsion-based organogels. Biochem. Eng. J., 12: 231-236

Nini, L., L. Sarda, L. C. Coumeau, E. Boitard, J. P. Dubes and H. Chahinian 2001 Lipase catalysed hydrolysis of short-chain substrates in solution and in emulsion: a kinetic study. Biochim. Biphys. Acta Molecular Cell Biol., 1534: 34-44

Ota Y., S. Miyairi and K. Yamada 1968 Sterol requirement for the lipase production by Candida cylindracea. Agr. Biol. Chem., 32 (12): 1476-1478

Papaparaskevas D., P. Christakopoulos, D. Kekos and B. J. Macris 1992 Optimizing production of extracellular lipase from Rhodotorula glutinis, Biotechnol. Letters, 14 (5): 397-402

Piao, J., T. Kobayashi, S. Adachi, K. Nakanishi and R. Matsuno 2003 Synthesis of mono- and di-oleoyl erythritols through immobilized lipase-catalyzed condensation of erythritol and oleic acid in acetone. Biochem. Eng. J., 14: 79-84

Raku, T., M. Kitagawa, H. Shimakawa and Y. Tokiwa 2003 Enzymatic synthesis of threalose esters having lipophilicity. J. Biotechnol., 100: 203-208

Salleh A. B., R. Musani and C. N. A. Razak 1993 Extra and intracellular lipases from a thermophilic Rhizopus oryzae and factors affecting their production. Can. J. Microbiol., 39: 978-981

Sarkar S., B. Sreekanth, S. Kant, R. Banerjee and B. C. Bhattacharyya 1998 Production and optimization of microbial lipase. Biopro. Eng., 19: 29-32

Saxena, R. K., P. K. Ghosh, R. Gupta, W. S. Davdison, S. Bradoo and R. Gulati 1999 Microbial lipases: Potential biocatalysts for the future industry. Curr. Sci., 77: 101-115

Shimada Y., Y. Sugihara, T. Nagae and Y. Tominaga 1992 Induction of Geotrichum candidum lipase by long-chain fatty acids. J. Ferment. Bioeng., 74 (2): 77-80

Shintre, M. S., R. S. Ghadge and S. B. Sawant 2002 Lipolase catalyzed synthesis of benzyl esters of fatty acids. Biochem. Eng. J., 12: 131-141

Sommer P., C. Bormann and F. Gotz 1997 Genetic and biochemical characterization of a new extracellular lipase from Streptomyces cinnamomeus. Appl. Environ. Microbiol., 63: 3553-3560

Sugihara A., Y. Shimada and Y. Tominaga 1990 Separation and characterization of two molecular forms of Geotrichum candidum lipase. J. Biochem., 107: 426-430

Wang Y., K. C. Srivastava, G. J. Shen and H. Y. Wang 1995 Thermostable alkaline lipase from a newly isolated thermophilic Bacillus strain, A30-1 (ATCC 53841). J. Ferment. Bioeng., 79: 433-438 